\title{
Pola Bakteri Aerob yang Berpotensi Menyebabkan Infeksi Nosokomial di Ruang Instalasi Bedah Sentral (IBS) RSUP Prof. Dr. R.D. Kandou Manado
}

\author{
${ }^{1}$ Tanya P. M. Putri \\ ${ }^{2}$ Olivia A. Waworuntu \\ ${ }^{2}$ Fredine E. S. Rares
}

${ }^{\mathbf{1}}$ Program Studi Pendidikan Dokter Fakultas Kedokteran Universitas Sam Ratulangi Manado
${ }_{2}$ Bagian Mikrobiologi Fakultas Kedokteran Universitas Sam Ratulangi Manado
Email: tpmputri@ gmail.com

\begin{abstract}
Nosocomial infections can be interpreted as infections that originate or could occur in hospitals and arise within 48 hours after being hospitalized up to 30 days patients off care. In Indonesia, namely in 10 Public Education Hospitals, the nosocomial infections percentage is $6-16 \%$ with an average of $9.8 \%$ in 2010 . This study was aimed to identifity the source and the bacteria pattern that caused nosocomial infections in the Intallation of Central Surgery Room (IBS) of Prof. Dr. R. D. Kandou Hospital Manado. This was a descriptive study with a prospective approach. Samples were bacteria on the wall, floor, air, furniture, and medical equipment in the IBS room of Prof. Dr. R. D. Kandou Hospital Manado. The results showed that of 4 wall samples, the most common bacteria were Bacillus sp. and Klebsiella pneumonia, each in 2 samples $(50 \%)$, Of the 5 floor samples, the most common bacteria were Staphylococcus $s p$. in 2 samples (40\%). Of the 15 air samples, the most common bacteria was Bacillus $s p$. in 7 samples (46.7\%). Of the 3 samples of medical equipment, the most common bacteria were Proteus vulgaris in 1 sample (33.3\%), Bacillus sp. in 1 sample (33.3\%), and Diplococcus in 1 sample (33.\%). Conclusion: Bacillus sp. is the most common bacteria found in IBS room of Prof. Dr. R. D. Kandou Hospital Manado.
\end{abstract}

Keywords: pattern of aerobic bacteria, nosocomial infections, central surgery room

\begin{abstract}
Abstrak: Infeksi nosokomial adalah infeksi yang berasal atau terjadi di rumah sakit yang timbul dalam kurun waktu 48 jam setelah dirawat di rumah sakit sampai dengan 30 hari lepas rawat. Di 10 RSU pendidikan di Indonesia didapatkan kejadian infeksi nosokomial cukup tinggi yaitu 6-16\% dengan rerata 9,8\% pada tahun 2010. Penelitian ini bertujuan untuk mengetahui sumber dan pola bakteri penyebab infeksi nosokomial yang terdapat diruang Instalasi Bedah Sentral (IBS) RSUP Prof. Dr. R. D. Kandou Manado. Jenis penelitian ialah deskriptif dengan pendekatan prospektif. Sampel penelitian ialah bakteri pada dinding, lantai, udara, perabotan, dan peralatan medis di ruang IBS RSUP Prof. Dr. R. D. Kandou Manado. Hasil penelitian memperlihatkan dari 4 sampel dinding, bakteri terbanyak yaitu Bacillus sp. dan Klebsiella pneumonia, masing-masing 2 sampel (50\%); dari 5 sampel lantai, bakteri terbanyak yaitu Staphylococcus sp. pada 2 sampel (40\%); dari 15 sampel udara, bakteri terbanyak yaitu Bacillus sp. pada 7 sampel (46,7\%). Dari 3 sampel peralatan medis didapatkan bakteri terbanyak yaitu Proteus vulgaris pada 1 sampel (33,3\%), Bacillus subtilis pada 1 sampel (33,3\%), dan Diplococcus pada 1 sampel (33,3\%). Simpulan: Bacillus sp. merupakan bakteri yang terbanyak ditemukan.
\end{abstract}

Kata kunci: pola bakteri aerob, infeksi nosokomial, ruang instalasi bedah sentral (IBS) 
Di Indonesia Rumah Sakit sebagai salah satu bagian sistem pelayanan kesehatan secara garis besar memberikan pelayanan untuk masyarakat berupa pelayanan medik, pelayanan penunjang medik, rehabilitasi medik, dan pelayanan perawatan. Pelayanan tersebut dilaksanakan melalui unit gawat darurat, unit rawat jalan, dan unit rawat inap. $^{1}$

Rumah sakit merupakan bagian integral organisasi pelayanan medik yang bertugas memberikan layanan kesehatan baik kuratif maupun preventif kepada masyarakat sekitar beserta lingkungannya. Kegiatan tersebut menimbulkan dampak positif dan negatif. Selain sebagai tempat untuk mencari kesembuhan, rumah sakit bisa juga merupakan sumber dari berbagai penyakit yang berasal dari penderita maupun pengunjung yang berstatus karier. Kuman penyakit ini dapat hidup dan berkembang di lingkungan rumah sakit, seperti udara, air, lantai, makanan, perabotan rumah sakit, dan peralatan medis maupun non medis. ${ }^{2}$ Pasien, petugas kesehatan, pengunjung dan penunggu pasien merupakan kelompok yang berisiko terkena infeksi nosokomial. ${ }^{2-3}$

Infeksi nosokomial terjadi di seluruh dunia, baik di negara sedang berkembang maupun negara maju. Kejadian terbanyak di negara yang sedang berkembang karena penyakit infeksi masih menjadi penyebab utama kesakitan dan kematian. Diperkirakan lebih dari $40 \%$ pasien di rumah sakit yang berada di negara berkembang terserang infeksi nosokomial. Di Indonesia yaitu di 10 RSU pendidikan, infeksi nosokomial cukup tinggi yaitu 6-16\% dengan rerata $9,8 \%$ pada tahun 2010 . Berdasarkan penelitian pola kuman pada meja operasi, lantai, dan udara di kamar operasi cito/ UGD RSUP Prof. Dr. R. D. Kandou Manado tahun 2010 didapatkan bakteri terbanyak yaitu Bacillus subtilis, yang juga merupakan penyebab infeksi nosokomial. Infeksi nosokomial paling umum terjadi ialah infeksi luka operasi (ILO). Hasil penelitian terdahulu menunjukkan bahwa angka kejadian ILO pada rumah sakit di Indonesia bervariasi antara $2-18 \%$ dari keseluruhan prosedur pembedahan. ${ }^{4-9}$

\section{METODE PENELITIAN}

Jenis penelitian ini ialah deskriptif dengan pendekatan prospektif untuk melihat pola bakteri yang berpotensi menyebabkan infeksi nosokomial di dinding, lantai, peralatan medis, dan udara di ruang Instalasi Bedah Sentral (IBS) RSUP Prof. Dr. R. D. Kandou Manado. Sampel bakteri diambil dari permukaan lantai, dinding, perabotan (tempat tidur dan tiang infus), peralatan medis (masker oksigen), dan udara di ruang IBS RSUP. Prof. Dr. R. D. Kandou Manado. Pemeriksaan sampel mikroorganisme yang berpotensi menyebabkan penularan infeksi nosokomial dilakukan di Laboratorium Mikrobiologi Fakultas Kedokteran Universitas Sam Ratulangi Manado.

\section{HASIL PENELITIAN}

Pengambilan sampel dilakukan pada 1 kamar operasi yang terdiri dari 27 sampel yaitu 4 sampel dinding, 5 sampel lantai, dan 15 sampel udara (pagi, siang, dan sore).

Tabel 1 memperlihatkan bahwa dari 27 sampel yang diteliti, bakteri yang tumbuh pada agar Nutrient berjumlah 21 sampel (77,8\%), pada agar Mac Conkey 7 sampel (26\%), dan pada agar darah 13 sampel (48\%). Yang tidak memperlihatkan partumbuhan bakteri ialah dari 27 sampel yang di teliti, yaitu pada agar nutrient berjumlah 6 sampel (22,2\%), pada agar Mac Conkey berjumlah 20 sampel (74\%), dan pada agar darah berjumlah 14 sampel (52\%).

Tabel 2 menunjukkan pada pemeriksaan Gram didapatkan bakteri Gram negatif 8 sampel $(36,4 \%)$ dan bakteri Gram positif 18 sampel $(63,6 \%)$.

Tabel 3 memperlihatkan bahwa pada sampel dinding diperoleh 2 jenis kuman dari 4 sampel dinding yang terdiri dari Bacillus sp. 2 sampel (50\%) dan Klebsiella pneumonia 2 sampel (50\%). 
Tabel 1. Distribusi pertumbuhan bakteri

\begin{tabular}{llllllc}
\hline Perbenihan & & \multicolumn{4}{c}{ Media Isolasi } \\
& & Jumlah & \multicolumn{4}{c}{ Persentase (\%) } \\
\hline \multirow{3}{*}{ Ada pertumbuhan } & NA & MC & AD & NA & MC & AD \\
Tidak ada pertumbuhan & 21 & 7 & 13 & 77,8 & 26 & 48 \\
Total & 6 & 20 & 14 & 22,2 & 74 & 52 \\
& 27 & 27 & 27 & $\mathbf{1 0 0}$ & $\mathbf{1 0 0}$ & $\mathbf{1 0 0}$ \\
\hline
\end{tabular}

Keterangan: NA (nutrient agar), MC (agar Mac Conkey), AD (agar darah).

Tabel 2. Hasil pewaranaan Gram

\begin{tabular}{ccc}
\hline $\begin{array}{c}\text { Pewarnaan } \\
\text { Gram }\end{array}$ & Frekuensi & $\begin{array}{c}\text { Persentase } \\
(\boldsymbol{\%})\end{array}$ \\
\hline Gram positif & 14 & 63,6 \\
Gram negatif & 8 & 36,4 \\
Total & 22 & 100 \\
\hline
\end{tabular}

Tabel 3. Pertumbuhan bakteri sampel dinding

\begin{tabular}{lcc}
\hline \multicolumn{1}{c}{ Bakteri } & Jumlah & $\begin{array}{c}\text { Persentase } \\
(\boldsymbol{\%})\end{array}$ \\
\hline Bacillus sp & 2 & 50 \\
K. pneumonia & 2 & 50 \\
Total & 4 & 100 \\
\hline
\end{tabular}

Tabel 4 menunjukkan 4 jenis kuman dari 5 sampel lantai yang terdiri dari Klebsiella pneumonia 1 sampel (20\%), kokus Gram negatif 1 sampel (20\%), Bacillus sp. 1 sampel (20\%), dan Staphylococcus sp. 2 sampel (40\%).

Tabel 4. Pertumbuhan bakteri sampel lantai

\begin{tabular}{lcc}
\hline \multicolumn{1}{c}{ Bakteri } & Jumlah & $\begin{array}{c}\text { Persentase } \\
(\mathbf{\%})\end{array}$ \\
\hline K. pneumoniae & 1 & 20 \\
Kokus Gram positif & 1 & 20 \\
Bacillus sp. & 1 & 20 \\
Staphylococcus sp. & 2 & 40 \\
Total & 5 & 100 \\
\hline
\end{tabular}

Tabel 5 menyajikan pertumbuhan bakteri dari sampel udara yang memperlihatkan 6 jenis bakteri dari 15 sampel, terdiri dari Staphylococcus sp. 2 sampel $(13,3 \%)$, kokus Gram negatif 1 sampel (6,66\%), Bacillus sp. 7 sampel $(46,7 \%)$, kokus Gram positif 1 sampel $(6,66 \%)$, Klebsiella pneumonia 3 sampel (20\%), dan Serrattia liquefaciance 1 sampel $(6,66 \%)$.

Tabel 6 menampilkan pertumbuhan bakteri dari sampel peralatan di ruang operasi yang mendapatkan 3 jenis bakteri dari 3 sampel yaitu Proteus vulgaris pada 1 sampel (33,3\%), Bacillus sp. pada 1 sampel (33,3\%), dan Diplococcus pada 1 sampel $(33,3 \%)$.

Tabel 5. Pertumbuhan bakteri sampel udara

\begin{tabular}{lcc}
\hline \multicolumn{1}{c}{ Bakteri } & Jumlah & $\begin{array}{c}\text { Persentase } \\
(\mathbf{\%})\end{array}$ \\
\hline Staphylococcus sp. & 2 & 13,3 \\
Kokus Gram negatif & 1 & 6,66 \\
Bacillus sp. & 7 & 46,7 \\
Kokus Gram positif & 1 & 6,66 \\
K. pneumonia & 3 & 20 \\
Serratia liquefaciens & 1 & 6,66 \\
Total & 15 & 100 \\
\hline
\end{tabular}

Tabel 6. Pertumbuhan sampel bakteri pada peralatan di ruang operasi

\begin{tabular}{lcc}
\hline \multicolumn{1}{c}{ Bakteri } & Jumlah & $\begin{array}{c}\text { Persentase } \\
(\boldsymbol{\%})\end{array}$ \\
\hline Proteus vulgaris & 1 & 33,3 \\
Bacillus sp. & 1 & 33,3 \\
Diplococcus & 1 & 33,3 \\
Total & 3 & 100 \\
\hline
\end{tabular}

\section{BAHASAN}

Hasil penelitian ini memperlihatkan bahwa Bacillus sp ialah bakteri yang paling banyak ditemukan yaitu sebanyak 7 dari 22 sampel (31,3\%), disusul oleh Klebsiella pneumonia (27,3\%), Staphylococcus sp. (13,7\%), kokus Gram positif (9\%), Serratia liquefaciens, Proteus vulgaris, Diplococcus, dan kokus Gram negatif (masingmasing 4,54\%).

Pada sampel dinding, Bacillus sp dan Klebsiella pneumonia ialah bakteri yang terbanyak ditemukan pada 4 sampel dinding masing-masing sebanyak 2 sampel (50\%). Bacillus sp merupakan bakteri yang 
paling banyak tumbuh dalam media agar pada penelitian ini dengan jumlah 17 media agar $(40,7 \%)$ dan hampir seluruh bagian ruangan media agarnya ditumbuhi oleh bakteri ini. Sampel yang ditumbuhi bakteri ini yaitu dinding, lantai, udara pagi, udara sore, dan tempat tidur.

Bakteri Bacillus sp bersifat non-patogenik bila dalam jumlah kecil, memiliki toksigenitas rendah seperti genus lainnya, dan daya virulensinya rendah. ${ }^{10,11}$ Hasil penelitian ini sejalan dengan penelitian Sofyan et $\mathrm{al}^{12}$ yang dilakukan di kamar operasi Cito BLU RSUP Prof. Dr. R. D. Kandou Manado yang melaporkan bakteri yang paling banyak ditemukan sebanyak 9 sampel berasal dari dinding, lantai. dan udara.

Klebsiella Pneumonia ialah bakteri bakteri kedua terbanyak yang ditemukan dalam penelitian ini. Bakteri ini tumbuh sebanyak 7 media agar $(25,9 \%)$, pada sampel dinding, lantai, udara siang dan udara malam. Klebsiella pneumonia merupakan bakteri Gram negatif, non-motil, memiliki kapsul, memfermentasi laktosa dan termasuk kelompok bakteri Enterobacteriaceae. $^{10,11}$ Pada penelitian yang dilakukan Raihanna ${ }^{13}$ di Bangsal Bedah RSUP DR. M. Djamil Padang didapatkan bahwa bakteri Klebsiella pneumonia 23,52\% ditemukan pada pasien infeksi luka operasi. Klebsiella pneumonia umumnya menyerang orang dengan kekebalan tubuh lemah, pasien pasca operasi, dan juga udara di ruang operasi atau ruang rawat inap yang belum bisa dipastikan kebersihannya. ${ }^{13,14}$

Media Kesehatan Masyarakat Indonesia, Vol. 11 / No.1, April 2012

Staphylococcus sp. merupakan flora normal pada kulit dan selaput lendir manusia. Pada penelitian ini, bakteri Staphylococcus sp. ini tumbuh pada 6 media agar $(22,2 \%)$. Perpindahan melalui tangan medis juga dapat menjadi transpor kuman untuk berpindah. Hal ini mengakibatkan bakteri ini bisa berada pada siklus udara ruang perawatan intensif anak yang terjadi pertukaran udara melalui AC menjadi tempat hidup bakteri. ${ }^{15}$

Bakteri kokus Gram negatif tumbuh pada 2 media agar $(7,4 \%)$ dan masingmasing juga ditemukan pada sampel lantai dan udara siang. Staphylococcus aureus dan Enterococcus ialah bakteri yang paling banyak menyebabkan infeksi nosokomial. Yang termasuk dalam kokus Gram positif yaitu Staphylococcus aureus, Staphylococcus epidermis, Streptococcus pyogenes, dan Streptococcus pneumonia. ${ }^{16}$

Pada penelitian ini didapatkan Serratia liquifaciens dan Proteus vulgaris tumbuh masing-masing pada 1 sampel $(33,3 \%)$ yaitu pada sampel udara siang, tiang infus, dan sungkup atau masker oksigen. Serratia liquifaciens merupakan bakteri Gram negatif dan masuk dalam family Enterobactericeae. ${ }^{19}$ Bakteri ini dapat menyebabkan pneuomia, bakteremia, dan endokarditis terutama pada pasien yang dirawat di rumah sakit. Proteus vulgaris adalah kelompok bakteri Gram negatif yang menimbulkan infeksi pada manusia hanya bila bakteri keluar dari saluran cerna. ${ }^{11,17}$

\section{SIMPULAN}

Berdasarkan hasil penelitian ini dapat disimpulkan bahwa Bacillus sp merupakan bakteri yang terbanyak ditemukan di ruang Instalasi Bedah Sentral (IBS) RSUP Prof. Dr. R. D. Kandou Manado.

\section{DAFTAR PUSTAKA}

1. Septriati BB. Infeksi Nosokomial (1st ed). Yogyakarta: Nuha Medika, 2012.

2. Mustika O. Angka dan pola kuman pada dinding, lantai, dan udara di ruang ICU RSUD Dr. Moewardi Surakarta [Skripsi]. Universitas Muhammadiyah Surakarta; 2013.

3. Depkes RI. Pedoman Pelaksanaan Kewaspadaan Universal di Pelayanan Kesehatan. Jakarta, 2003.

4. Zulkarnain I. Infeksi nosokomial. Buku Ajar Ilmu Penyakit Dalam III (5th ed). Jakarta: Fakultas Kedokteran Universitas Indonesia, 2009; p. 2906-10. Jakarta.

5. Nugraheni R, Suhartono, Wiharni S. Infeksi nosokomial di RSUD Setjonegoro Kabupaten Wonosobo. Media Kesehatan Masyarakat Indonesia. 2010; 11(1):94-100. 
6. Djojosugito A, Roeshadi DJ, Pusponegoro A, Supardi I. Buku Manual Pengendalian Infeksi Nosokomial di Rumah Sakit. Jakarta: IDI, 2001.

7. Mehta Y. Guideline for Prevention Hospitals Acquired Infections. J Crit Care Med. 2014;18(3):149-63.

8. Tanjung M. Pola kuman pada kamar operasi \& ruang perawatan bedah di RS. Prof. R. D. Kandou [Tesis]. Manado: Fakultas Kedokteran Universitas Sam Ratulangi; 2010.

9. Jeyamohan, Dharshini. Angka prevalensi infeksi nosokomial pada pasien luka oprasi pasca bedah di Rumah Sakit Umum Pusat Haji Adam Malik, Medan dari Bulan April sampai September 2010. Medan: Unversitas Sumatera Utara; 2010.

10. Gillespie, Bamford. At a Glance Mikrobiologi Medis dan Infeksi (3rd ed). Jakarta: Erlangga, 2009; p. 12,13.

11. Jawetz, Melnick, Adelberg. Mikrobiologi Kedokteran (23rd ed). Jakarta: EGC, 2004; p. 149-94.

12. Sofyan AF, Homenmta H, Rares F. Pola bakteri aerob yang berpotensi menyebabkan infeksi nosokomial di kamar operasi cito BLU RSUP Prof. Dr. R. D. Kandou Manado. eBm. 2015;3(1):3815.

13. Raihanna N. Profil kultur uji sensitivitas bakteri aerob dan infeksi luka operasi laparotomi di bangsal bedah RSUP DR. M. Djamil Padang. Padang: Universitas Andalas; 2011.

14. Ravichitra KN, Prakash PH, Subbarayudu S, Sreenivassa Rao U. Isolation and antibiotic sensitivity of Klebsiella pneumonia from pus, sputum and urine samples. Int J Curr Microbial App Sci. 2014;3(3):115-9.

15. Baharutan A, Rares FES, Soeliongan S. Pola bakteri penyebab infeksi nosokomial pada Ruang Perawatan Intensif Anak di BLU RSUP Prof. Dr. R. D. Kandou Manado. eBm. 2015;3(1):4129.

16. Jeljaszewicz J1, Mlynarczyk G, Mlynarczyk A. Antibiotic resistance in Gram-positive cocci. Int J Antimicrob Agents. 2000;16(4):473-8.

17. Phan H, Lehman D. Cerebral abscess complicating Proteus mirabilis meningitis in a newborn infant. J Child Neurol. 2012;27(3):405-7. 